International Journal of Current Microbiology and Applied Sciences

ISSN: 2319-7706 Volume 6 Number 7 (2017) pp. 1023-1034

Journal homepage: http://www.ijcmas.com

Original Research Article

https://doi.org/10.20546/ijcmas.2017.607.123

\title{
Physiological Indices, Yield and Yield Attributes of Quinoa (Chenopodium quinoa Willd.) as Influenced by Dates of Sowing and Varied Crop Geometry
}

\author{
K. Ramesh ${ }^{1 *}$, K.B. Suneetha Devi ${ }^{1}$, K.A. Gopinath ${ }^{2}$ and M. Uma Devi ${ }^{3}$ \\ ${ }^{1}$ Department of Agronomy, College of Agriculture, Professor Jayashankar Telangana State \\ Agricultural University, Rajendranagar, Hyderabad-500030, Telangana, India \\ ${ }^{2}$ Agronomy, AICRP for Dryland Agriculture, CRIDA, Santoshnagar, \\ Hyderabad, Telangana, India \\ ${ }^{3}$ SS\&AC, Water Technology Centre, D.J.B., Rajendranagar, \\ Hyderabad-500030, Telangana, India \\ *Corresponding author
}

\section{A B S T R A C T}

A field experiment was conducted at College farm, College of Agriculture, PJTSAU, Rajendranagar, Hyderabad during rabi 2015-16 to study the "Evaluation of quinoa (Chenopodium quinoa Willd.) at different dates of sowing

Keywords

Quinoa, Growing degree days, Photothermal units, Crop growth rate, RGR, NAR.

Article Info

Accepted:

17 June 2017

Available Online:

10 July 2017 and varied crop geometry in semi-arid regions of Telangana." The experiment was laid out in split plot design with three replications to test three dates of sowing $\left(\mathrm{D}_{1}: 15^{\text {th }}\right.$ October, $\mathrm{D}_{2}: 1^{\text {st }}$ November and $\mathrm{D}_{3}: 16^{\text {th }}$ November $)$ and to standardise the crop geometry $\left(\mathrm{S}_{1}: 10 \times 15 \mathrm{~cm}, \mathrm{~S}_{2}: 10 \times 30 \mathrm{~cm}, \mathrm{~S}_{3}: 10 \times 45 \mathrm{~cm}\right.$ and $\left.\mathrm{S}_{4}: 10 \times 60 \mathrm{~cm}\right)$. Higher crop growth rate, Relative growth rate, total growing degree days and photothermal units was obtained on 15 th October date of sowing . H igher CGR was recorded with $15 \times 10 \quad$ mc spacings, whereas higher RGR and NAR were obtained under $60 \times 10 \quad$ mc spacing. The maximum seed, stalk yield was obtained with 15 th October date of sowing along with narrow $(15 \times 10 \mathrm{mc})$ spacing and was followed by $30 \times$ $10 \mathrm{mc}$. The number of branches plant ${ }^{-1}$, panicle length, number of spikelets panicle $^{-1}$ were higher with wider spacing $45 \times 10 \mathrm{mc}$ and $60 \times 10 \mathrm{mc}$ compared to narrow $(15 \times 10 \mathrm{mc})$ spacings. The higher number of grains panicle $^{-1}$ was recorded with $45 \times 10 \mathrm{mc}$ spacing.

\section{Introduction}

Quinoa is discovered as a healthy food by North Americans and Europeans in the 1970's and its popularity is dramatically increased in recent years because it is gluten-free (helpful for diabetic patients) and high in protein. In India, quinoa was cultivated in an area of 440 hectares with an average yield of 1053 tonnes (Srinivasa Rao, 2015). It is cultivated in the world with an area of 126 thousand hectares in a production of 103 thousand tonnes. Bolivia in South America is the biggest producer of quinoa with 46 per cent of world 
production followed by Peru with 42 per cent and United States of America with 6.3 per cent (FAOSTAT, 2013). As per United Nations Organisation for Agriculture and Food, the quinoa grain is the only vegetable food that provides all amino acids essential to the life of humans in optimum quantities and is comparable with milk. The protein and oil content ranges from 7.47 to 22.08 per cent and 1.8 to 9.5 per cent. FAO nominated 2013 as International year of Quinoa (Bhargava et al., 2006).

Growing period of quinoa varied between 70 to 200 days and some entries did not mature in some locations. The experiment conducted to evaluate quinoa entries in America, Europe and Africa and reported that growing period of quinoa in Kenya was 65-98 days and all cultivars matured with seed yield of $4000 \mathrm{~kg}$ $\mathrm{ha}^{-1}$.

In Denmark and Sweden, growing period was 120-160 days but yields were low and few varieties only matured. The growing period in Greece was 110-160 days and the yield was $2000 \mathrm{~kg} \mathrm{ha}^{-1}$ (Jacobsen, 2003)

It can play a major role in future diversification of agriculture system in India. Inspite of its wide adaptability, nutritional superiority, its commercial potential has remained untapped. Hence, an experiment was conducted entitled "Evaluation of Quinoa (Chenopodium quinoa willd.) At different dates of sowing and varied crop geometry in semi-arid regions of Telangana" during rabi season, 2015-16.

\section{Materials and Methods}

A field experiment was conducted at College farm, College of Agriculture, Professor Jayashankar Telangana State Agricultural University, Rajendranagar, Hyderabad during rabi 2015-16. The farm is geographically situated at an altitude of $542.3 \mathrm{~m}$ above mean sea level at $17^{0} 19^{\prime} \mathrm{N}$ latitude, $78^{0} 28^{\prime} \mathrm{E}$ longitude. The experiment was laid out in split plot design with three replications with three different dates of sowing ( $\quad \mathrm{D}_{1}: 15^{\text {th }}$ October, $\mathrm{D}_{2}: 1^{\text {st }}$ November and $\quad \mathrm{D}_{3}: 16^{\text {th }}$ November) as main plots and four crop geometry levels $\left(S_{1}: 15 \times 10 \mathrm{~cm}, S_{2}: 30 \times 10\right.$ $\mathrm{cm}, \mathrm{S}_{3}: 45 \times 10 \mathrm{~cm}$ and $\left.\mathrm{S}_{4}: 60 \times 10 \mathrm{~cm}\right)$ as sub plots under semi arid conditions of Telangana. The variety used was accession line of EC series (Golden yellow colour seed) . The weekly mean (maximum and minimum) temperature. Weekly mean relative humidity (maximum and minimum) 84.3 per cent and 39.5 per cent, Where as weekly mean sunshine hours, evaporation and wind velocity was $8.1 \mathrm{~h} \mathrm{day}^{-1}, 5.5 \mathrm{~mm}^{-1 a y}{ }^{-1}$ and 1.3 $\mathrm{km} \mathrm{h}^{-1}$ respectively and rain fall of $18.3 \mathrm{~mm}$ received in a single day during the crop growing seaon.

The experimental soil was sandy loam in texture, high organic carbon, medium in soil available nitrogen (258 $\mathrm{kg} \mathrm{ha}^{-1}$ ), phosphorus (25.3 kg ha $\mathrm{kg}^{-1}$, and potassium (238 $\left.\mathrm{kg} \mathrm{ha}^{-1}\right)$. Recommended dose of fertilizer i.e., $100 \mathrm{~kg}$ $\mathrm{N}, 50 \mathrm{~kg} \mathrm{P}_{2} \mathrm{O}_{5}$ and $50 \mathrm{~kg} \mathrm{~K}_{2} \mathrm{O} \mathrm{ha}^{-1}$ in the form of urea, single super phosphate and muriate of potash, respectively, Entire dose of $\mathrm{P}, \mathrm{K}$ and $1 / 2$ of $\mathrm{N}$ was applied as basal through placement in the furrows made with hand hoes $5 \mathrm{~cm}$ away from seed rows and at a depth of $2 \mathrm{~cm}$ below the seed zone. The remaining $1 / 2$ dose of $\mathrm{N}$ was applied in two more equal splits at 25 and 50 days after sowing. One irrigation was provided after sowing to facilitate uniform germination of the crop, and 5-6 irrigations were given at 1215 days interval. During the seedling stage, the crop was affected by leaf eating caterpillars and leaf miners those were controlled by spraying Quinolphos @ 2ml lit ${ }^{-1}$ of water. Data on growth and yield attributes from randomly selected five plants from each net plot was recorded and the mean value was 
worked out and yield was recorded from each net plot. The crop was harvested at 107, 101 and 97 days in three dates of sowing $\left(D_{1}: 15^{\text {th }}\right.$ October, $\mathrm{D}_{2}: 1^{\text {st }}$ November and $\quad \mathrm{D}_{3}: 16^{\text {th }}$ November) respectively. The physiological indices i.e., crop growth rate ( $\mathrm{CGR}$ ), relative growth rate ( $\mathrm{RGR})$, net assimilation rate (NAR) were calculated at monthly interval upto harvest, yield atrributes and yield were recorded and data was statistically analyzed by using WINDOSTAT Software Version-7. Significance of the treatments was determined on the basis of $\mathrm{F}$ test and critical difference was calculated at 5\% level of probability. Growing degree days ( GDD), photothermal units ( PTU) were calculated based on the following formulae.

GDD was calculated according to the formula of Rajput, (1980).

Growing Degree

days $=\sum_{i=1}^{n}\left(\frac{T_{\max }+\mathrm{Tmin}}{2}\right)-\mathrm{T}_{\mathrm{b}}$

Where,

$\mathrm{T}_{\mathrm{MAX}}$ is the daily maximum air temperature.

$\mathrm{T}_{\mathrm{MIN}}$ is the daily minimum air temperature, and

$\mathrm{T}_{\mathrm{b}}$ is the lowest temperature at which there is no growth

(Base Temperature)

$n=$ number of days between two stages of development

PTU was calculated according to the formula given by Major et al.,(1975).

$\mathrm{PTU}=\sum_{i=1}^{n} \mathrm{GDD} \times$ Day length

Where,

GDD $=$ Growing Degree Days

\section{Results and Discussion}

\section{Crop growth rate (CGR)}

Crop growth rate (CGR) is defined as the absolute measure of gain in growth (dry matter production) on a unit of land in a unit of time. It will denote the affinity of crop to convert solar energy in to economic growth (Table 1). Irrespective of dates of sowning and geometry levels crop growth rate of quinoa increased with advancement of crop age and reached its peak between 60-90 DAS and slightly declined at harvest (90 DAS harvest). October $15^{\text {th }}$ date of sowing showed higher crop growth rate between 30-60 DAS (5.4), 60-90 DAS (11.3) and 90 DAS-harvest (7.0) and at par with 1 st November date of sowing at all stages of crop growth. variation in CGR is mainly attributed to dry matter variation per uint area. CGR of 16 November date of sowing was significantly less at all crop growth stages of quinoa.

Among geometry levels, narrow spacing (15 $\times 10 \mathrm{~cm}$ ) produced significantly higher CGR $\left(\mathrm{g} \mathrm{m}^{-2} \mathrm{~d}^{-1}\right)$ during 30-60 DAS (6.7), 60-90 DAS (14.9) and 90 DAS - harvest (11.1) and closely followed by $30 \times 10 \mathrm{~cm}$ spacing (3.9, 10.2, and 8.0) at different crop growth periods respectively. The higher CGR values may be attributed to more number of plants and higher dry matter production on unit area basis. Followed to this, wider spacing produced significantly lower CGR at all growth stages. Though the individual plant canopy was increased in these spacings, CGR was decreased as the plant population and dry matter production on unit area basis was less.

\section{Relative growth rate (RGR)}

Relative growth rate is a measure of rate of dry matter increase per unit dry matter per unit time (Figures 1 and 2). The RGR was low at early phase of growth and increased 
between 30-60 DAS and againdecreased maturity. October 15 th date of sowing maintained higher RGR at 30-60 DAS, 60-90 DAS and at 90 DAS-harvest growth stages and superior over $1 \quad{ }^{\text {st }}$ November and 16 th November dates of sowing.

Relative growth rate was infuenced by various levels of crop geometries at different growth periods. The higher RGR was achieved under wider $60 \times 10 \quad \mathrm{~cm}$ spacing compared to closer $15 \times 10 \mathrm{~cm}$ spacing but the difference between the geometries was non significant at 90 DAS- harvest period of the crop. However, highest RGR was observed at 30-60 DAS under $15 \times 10 \mathrm{~cm}$ and at 60-90 DAS under wider $60 \times 10 \quad \mathrm{~cm}$ spacing superior over other crop geometries. This might be due to better performance of individual plant in terms of dry matter production under wider spacing because of utilisation of available resources such as sun light, water, nutrient and space which made higher relative growth rate under wider spacing compared to narrow spacing.

\section{Net assimilation rate (NAR)}

Net assimilation rate or unit leaf rate is the net gain of assimilate per unit of leaf area and unit time (Figures 3 and 4). The production of crop is dependent on its inherent capacity of net assimilation rate (NAR) and leaf area. As NAR dependent on leaf area similarly it was lower at early growth stage and peak at reproductive stage and decreased with advancement of crop growht period further. November $16^{\text {th }}$ date of sowing was superior over other dates of sowing. However, highest gain was observed at 60-90 DAS.

Increase in crop geometry of quinoa showed significant increase in NAR at all the crop growth periods. Maximum net gain of assimilates was observed under wider $60 \times 10$ $\mathrm{cm}$ spacing between 60-90 DAS which was signifiactly higher compared to closer spacing. While minimum NAR shown in figure at all stages of crop growth with closer spacing.

\section{Growing degree days (GDD)}

The crop sown on $15^{\text {th }}$ October date of sowing took 107 days to maturity followed by 101 and 97 days in $1 \quad{ }^{\text {st }}$ November and $16 \quad$ th November date of sowing respectively Jacobsen (2003) reported that growing period of quinoa varied between 70 to 200 days over Globe and some entries did not mature in some locations. $15^{\text {th }}$ October date of sowing showed optimum allocation of days to different phenological stages, i.e., vegetative (35 days), flowering (22 days), grain initiation to development (25 days) and grain maturity (13 days) and thus resulted in higher yield attributes and seed yield of quinoa with less vegetative growth (plant height, number of branches). The results were suported by Hirich et al., (2014) and Bertero (2001).

Contradictory to this, $1{ }^{\text {st }}$ November and $16^{\text {th }}$ November dates of sowing took less number of days for germination and establishment stage (10 and 9 days) respectively because of lower temperature $\left(21\right.$ to $\left.22{ }^{0} \mathrm{C}\right)$ but vegetative growth for more days ( 37 and 36 days). Hence, the plant height, number of branches, dry matter production of leaf and stem upto 60 DAS is higher compared to $15^{\text {th }}$ October date of sowing. Afterwards flowering period and grain initiation and development was reduced in $1{ }^{\text {st }}$ November (19 and 17 days) and $16^{\text {th }}$ November (22 and 21 days) date of sowing respectively. This resulted in less partitioning of dry matter to reproductive parts and reduced seed yield of quinoa. The grain hardening and maturity stage was not affected by sowing dates. Growing degree days represents influence of temperature on growth and development of crop (Table 2). 
Table.1 Effect of sowing dates and varied crop geometry on crop growth rate (CGR) $\left(\mathrm{gm}^{-2} \mathrm{~d}^{-1}\right)$

\begin{tabular}{|c|c|c|c|}
\hline Treatments & 30-60 DAS & 60-90 DAS & 90 DAS -Harvest \\
\hline \multicolumn{4}{|l|}{ Main: Sowing dates } \\
\hline $\mathrm{D}_{1}:$ October 15 & 5.4 & 11.3 & 7.0 \\
\hline $\mathrm{D}_{2}$ :November 1 & 5.1 & 10.4 & 5.3 \\
\hline $\mathrm{D}_{3}$ :November 16 & 4.4 & 8.6 & 4.4 \\
\hline SEm \pm & 0.1 & 0.9 & 0.7 \\
\hline $\mathrm{CD}(\mathrm{P}=0.05)$ & 0.3 & 2.4 & 2.0 \\
\hline $\mathrm{CV}(\%)$ & 7.1 & 10.6 & 11.3 \\
\hline \multicolumn{4}{|l|}{ Sub: Geometrylevels } \\
\hline $\mathrm{S}_{1}: 15 \times 10 \mathrm{~cm}$ & 6.7 & 14.9 & 11.1 \\
\hline $\mathrm{S}_{2}: 30 \times 10 \mathrm{~cm}$ & 3.9 & 10.2 & 8.0 \\
\hline $\mathrm{S}_{3}: 45 \times 10 \mathrm{~cm}$ & 4.5 & 8.3 & 7.2 \\
\hline $\mathrm{S}_{4}: 60 \times 10 \mathrm{~cm}$ & 4.9 & 6.9 & 6.1 \\
\hline $\mathrm{SEm} \pm$ & 0.1 & 0.6 & 0.5 \\
\hline $\mathrm{CD}(\mathrm{P}=0.05)$ & 0.4 & 1.3 & 1.5 \\
\hline $\mathrm{CV}(\%)$ & 8.14 & 13.7 & 14.1 \\
\hline \multicolumn{4}{|l|}{ Interaction } \\
\hline \multicolumn{4}{|l|}{$\mathrm{D} \times \mathrm{S}$ (main at samelevel of sub) } \\
\hline $\mathrm{SEm} \pm$ & 0.3 & 1.1 & 0.9 \\
\hline $\mathrm{CD}(\mathrm{P}=0.05)$ & 0.7 & 2.3 & NS \\
\hline \multicolumn{4}{|c|}{$\mathrm{S} \times \mathrm{D}$ (sub at same or different level of main) } \\
\hline $\mathrm{SEm} \pm$ & 0.3 & 1.3 & 1.1 \\
\hline $\mathrm{CD}(\mathrm{P}=0.05)$ & 0.7 & 3.2 & NS \\
\hline
\end{tabular}

Table.1a Interaction between sowing dates and varied crop geometry on CGR of quinoa at 30-60 DASand 60-90 DAS

CGR at 30-60 DAS

\begin{tabular}{|c|c|c|c|c|c|}
\hline \multirow[t]{2}{*}{ Treatments } & \multicolumn{5}{|c|}{ Crop geometry $(\mathrm{cm})$} \\
\hline & $15 \times 10$ & $30 \times 10$ & $45 \times 10$ & $60 \times 10$ & Mean \\
\hline \multicolumn{6}{|l|}{ Sowing dates } \\
\hline October15 & 9.8 & 5.3 & 3.0 & 3.1 & 5.4 \\
\hline November1 & 6.5 & 3.0 & 5.0 & 6.0 & 5.1 \\
\hline November16 & 3.7 & 2.9 & 5.4 & 5.6 & 4.4 \\
\hline Mean & 6.7 & 3.9 & 4.5 & 4.9 & \\
\hline \multicolumn{6}{|l|}{ Interaction } \\
\hline $\mathrm{D} \times \mathrm{S}$ & $\mathrm{SEm} \pm$ & 0.3 & $\mathrm{CD}(\mathrm{P}=0.05)$ & 0.7 & \\
\hline $\mathrm{S} \times \mathrm{D}$ & $\mathrm{SEm} \pm$ & 0.3 & $\mathrm{CD}(\mathrm{P}=0.05)$ & 0.7 & \\
\hline \multicolumn{6}{|c|}{ CGR at 60-90 DAS } \\
\hline \multirow[t]{2}{*}{ Treatments } & \multicolumn{5}{|c|}{ Crop geometry $(\mathrm{cm})$} \\
\hline & $15 \times 10$ & $30 \times 10$ & $45 \times 10$ & $60 \times 10$ & Mean \\
\hline \multicolumn{6}{|l|}{ Sowing dates } \\
\hline October15 & 18.9 & 11.4 & 8.1 & 6.8 & 11.3 \\
\hline November1 & 14.8 & 9.8 & 9.2 & 7.7 & 10.4 \\
\hline November16 & 11.1 & 9.3 & 7.5 & 6.4 & 8.5 \\
\hline Mean & 14.9 & 10.2 & 8.3 & 6.69 & \\
\hline \multicolumn{6}{|l|}{ Interaction } \\
\hline $\mathrm{D} \times \mathrm{S}$ & $\mathrm{SEm} \pm$ & 1.1 & $\mathrm{CD}(\mathrm{P}=0.05)$ & 2.3 & \\
\hline $\mathrm{S} \times \mathrm{D}$ & $\mathrm{SEm} \pm$ & 1.3 & $\mathrm{CD}(\mathrm{P}=0.05)$ & 3.2 & \\
\hline
\end{tabular}


Table.2 Growing degree days and photothermal units during different phenophases of as influenced by dates of sowing of Quinoa

\begin{tabular}{|c|c|c|}
\hline Phenophase & $\begin{array}{c}\text { Growing degree days } \\
\text { (GDD) }\end{array}$ & $\begin{array}{c}\text { Photothermal unit } \\
\text { (PTU) }\end{array}$ \\
\hline \multicolumn{3}{|l|}{$\mathrm{D}_{1}$ : October 15 - Jan.27 } \\
\hline Germination and Establishment (12 days) & 272.5 & 3174.6 \\
\hline Vegetative (35 days) & 726.8 & 8234.6 \\
\hline Flowering (22 days) & 431.2 & 4764.7 \\
\hline Grain initiation andDevelopment ( 25 days) & 415.8 & 4569.6 \\
\hline Grain hardening and Maturity (13 days) & 272.8 & 3017.1 \\
\hline Total (107 days) & 2119.1 & 23760.8 \\
\hline \multicolumn{3}{|l|}{$\mathrm{D}_{2}:$ November 1 - Feb.7 } \\
\hline Germination and Establishment (10 days) & 219.8 & 2503.5 \\
\hline Vegetative (37 days) & 739.6 & 8483.2 \\
\hline Flowering (19 days) & 325.2 & 3573.9 \\
\hline Grain initiation andDevelopment ( 22 days) & 409.0 & 4511.2 \\
\hline Grain hardening and Maturity (13 days) & 267.5 & 2987.9 \\
\hline Total (101 days) & 1959.3 & 22059.9 \\
\hline \multicolumn{3}{|l|}{$\mathrm{D}_{3}$ :November 16 - Feb.17 } \\
\hline Germination and Establishment (9 days) & 186.9 & 2095.1 \\
\hline Vegetative (36 days) & 723.3 & 7992.4 \\
\hline Flowering (17 days) & 265.7 & 2922.7 \\
\hline Grain initiation andDevelopment (21 days) & 399.4 & 4437.3 \\
\hline Grain hardening and Maturity (14 days) & 282.2 & 3188.8 \\
\hline Total (97 days) & 1857.5 & 20636 \\
\hline
\end{tabular}


Table.3 Yield attributes and yield of quinoa (Chenopodium quinoa Willd.) as influenced by

Dates of sowing and varied crop geometry

\begin{tabular}{|c|c|c|c|c|c|c|c|}
\hline Treatments & $\begin{array}{l}\text { Panicle length } \\
(\mathrm{cm})\end{array}$ & $\begin{array}{c}\text { Number of } \\
\text { panicles plant }^{-1}\end{array}$ & $\begin{array}{l}\text { Number of } \\
\text { spikelets panicle }^{-1}\end{array}$ & $\begin{array}{c}\text { Number of grains } \\
\text { panicle }^{-1}\end{array}$ & $\begin{array}{l}\text { Panicle weight } \\
\left(\mathrm{g} \mathrm{m}^{-2}\right)\end{array}$ & $\begin{array}{c}\text { Seed yield } \\
\left(\mathrm{kg} \mathrm{ha}^{-1}\right)\end{array}$ & $\begin{array}{c}\text { Stalk yield } \\
\left(\mathrm{kg} \mathrm{ha}^{-1}\right)\end{array}$ \\
\hline \multicolumn{8}{|l|}{ Main: Sowing dates } \\
\hline $\mathrm{D}_{1}:$ October 15 & 25.3 & 12.3 & 110.5 & 11562 & 487.5 & 2001 & 2293 \\
\hline $\mathrm{D}_{2}:$ November 1 & 22.7 & 13.8 & 104.1 & 4842 & 470.1 & 1610 & 2036 \\
\hline $\mathrm{D}_{3}$ :November 16 & 17.8 & 13.1 & 102.0 & 5314 & 430.2 & 1477 & 1877 \\
\hline SEm \pm & 0.4 & 0.3 & 4.4 & 321 & 18.0 & 52 & 85 \\
\hline $\mathrm{CD}(\mathrm{P}=0.05)$ & 1.2 & 1.0 & $\mathrm{NS}$ & 803 & 52.2 & 145 & 236 \\
\hline $\mathrm{CV}(\%)$ & 5.0 & 7.0 & 10.2 & 10.7 & 9.5 & 7.5 & 10.7 \\
\hline \multicolumn{8}{|l|}{ Sub: Spacings } \\
\hline $\mathrm{S}_{1}: 15 \times 10 \mathrm{~cm}$ & 19.0 & 9.9 & 81.0 & 4196 & 677.9 & 2070 & 2417 \\
\hline $\mathrm{S}_{2}: 30 \times 10 \mathrm{~cm}$ & 22.1 & 12.0 & 105.8 & 6199 & 448.3 & 1764 & 2186 \\
\hline $\mathrm{S}_{3}: 45 \times 10 \mathrm{~cm}$ & 23.5 & 14.7 & 113.5 & 9823 & 394.5 & 1491 & 1895 \\
\hline $\mathrm{S}_{4}: 60 \times 10 \mathrm{~cm}$ & 23.3 & 15.6 & 121.7 & 8738 & 329.6 & 1460 & 1777 \\
\hline $\mathrm{SEm} \pm$ & 0.6 & 0.9 & 7.9 & 224 & 15.2 & 28 & 61 \\
\hline $\mathrm{CD}(\mathrm{P}=0.05)$ & 1.3 & 2.0 & 16.6 & 561 & 32.0 & 59 & 128 \\
\hline $\mathrm{CV}(\%)$ & 6.2 & 13.6 & 13.1 & 12.2 & 6.9 & 3.5 & 6.2 \\
\hline \multicolumn{8}{|l|}{ Interaction } \\
\hline \multicolumn{8}{|l|}{$\mathrm{D} \times \mathrm{S}$} \\
\hline $\mathrm{SEm} \pm$ & 1.1 & 1.6 & 13.7 & 1085 & 26.3 & 49 & 105 \\
\hline $\mathrm{CD}(\mathrm{P}=0.05)$ & 2.3 & NS & $\mathrm{NS}$ & 2279 & 55.4 & 102 & NS \\
\hline \multicolumn{8}{|l|}{$\mathrm{S} \times \mathrm{D}$} \\
\hline $\mathrm{SEm} \pm$ & 1.0 & 1.5 & 12.6 & 1267 & 29.1 & 67 & 125 \\
\hline $\mathrm{CD}(\mathrm{P}=0.05)$ & 2.3 & NS & $\mathrm{NS}$ & 3048 & 68.8 & 169 & NS \\
\hline
\end{tabular}

Table.3a Interaction between sowing dates and varied crop geometry on Number of grains panicle ${ }^{-1}$, Panicle weight $\left(\mathrm{gm}^{-2}\right)$ and Seed yield $\left(\mathrm{kg} \mathrm{ha}^{-1}\right)$ of quinoa

\begin{tabular}{|c|c|c|c|c|c|}
\hline \multirow{2}{*}{ Treatments } & \multicolumn{5}{|c|}{ Crop geometry (cm) } \\
\hline & $15 \times 10$ & $30 \times 10$ & $45 \times 10$ & $60 \times 10$ & Mean \\
\hline \multicolumn{6}{|l|}{ Sowing dates } \\
\hline October15 & 5250 & 8668 & 18877 & 13452 & 11562 \\
\hline November1 & 3290 & 4468 & 6125 & 5483 & 4842 \\
\hline November16 & 4048 & 5460 & 4468 & 7280 & 5314 \\
\hline Mean & 4196 & 6199 & 9823 & 8738 & \\
\hline \multicolumn{6}{|l|}{ Interaction } \\
\hline $\mathrm{D} \times \mathrm{S}$ & SEm \pm & 1085.09 & $\mathrm{CD}(\mathrm{P}=0.05)$ & 2279.7 & \\
\hline $\mathrm{S} \times \mathrm{D}$ & SEm \pm & 1267.3 & $\mathrm{CD}(\mathrm{P}=0.05)$ & 3048.0 & \\
\hline
\end{tabular}


Panicle weight

\begin{tabular}{|c|c|c|c|c|c|}
\hline \multirow[t]{2}{*}{ Treatments } & \multicolumn{5}{|c|}{ Crop geometry $(\mathrm{cm})$} \\
\hline & $15 \times 10$ & $30 \times 10$ & $45 \times 10$ & $60 \times 10$ & Mean \\
\hline \multicolumn{6}{|l|}{ Sowing dates } \\
\hline October15 & 725.2 & 456.1 & 398.4 & 370.2 & 487.5 \\
\hline November1 & 730.0 & 415.6 & 411.1 & 323.6 & 470.1 \\
\hline November16 & 578.6 & 473.1 & 374.1 & 294.9 & 430.2 \\
\hline Mean & 677.9 & 448.3 & 394.5 & 329.6 & \\
\hline \multicolumn{6}{|l|}{ Interaction } \\
\hline $\mathrm{D} \times \mathrm{S}$ & SEm \pm & 26.3 & $\mathrm{CD}(\mathrm{P}=0.05)$ & 55.4 & \\
\hline $\mathrm{S} \times \mathrm{D}$ & $\mathrm{SEm} \pm$ & 29.1 & $\mathrm{CD}(\mathrm{P}=0.05)$ & 68.8 & \\
\hline
\end{tabular}

\begin{tabular}{|c|c|c|c|c|c|}
\hline \multicolumn{6}{|c|}{ Seed yield } \\
\hline \multirow[t]{2}{*}{ Treatments } & \multicolumn{5}{|c|}{ Crop geometry $(\mathrm{cm})$} \\
\hline & $15 \times 10$ & $30 \times 10$ & $45 \times 10$ & $60 \times 10$ & Mean \\
\hline \multicolumn{6}{|l|}{ Sowing dates } \\
\hline October15 & 2392 & 2083 & 1786 & 1744 & 2001 \\
\hline November1 & 2064 & 1620 & 1396 & 1361 & 1610 \\
\hline November16 & 1755 & 1587 & 1290 & 1276 & 1477 \\
\hline Mean & 2070 & 1764 & 1491 & 1460 & \\
\hline \multicolumn{6}{|l|}{ Interaction } \\
\hline $\mathrm{D} \times \mathrm{S}$ & $\mathrm{SEm} \pm$ & 49 & $\mathrm{CD}(\mathrm{P}=0.05)$ & 102 & \\
\hline $\mathrm{S} \times \mathrm{D}$ & $\mathrm{SEm} \pm$ & 67 & $\mathrm{CD}(\mathrm{P}=0.05)$ & 169 & \\
\hline
\end{tabular}

Fig.1 Relative growth rate $\left(\mathrm{gg}^{-1} \mathrm{day}^{-1}\right)(\mathrm{RGR})$ of quinoa at different stages of crop growth as influenced by dates of sowing

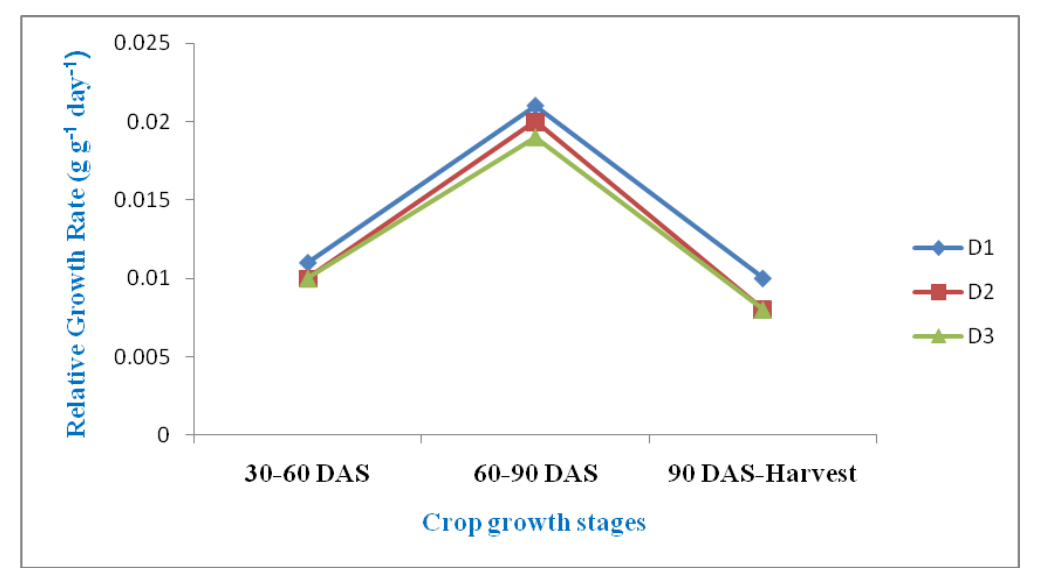

$\mathrm{D}_{1}: 15^{\text {th }}$ October, $\mathrm{D}_{2}: 1^{\text {st }}$ November $\mathrm{D}_{3}: 16^{\text {th }}$ November

Fig.2 Relative growth rate $\left(\mathrm{gg}^{-1} \mathrm{day}^{-1}\right)(\mathrm{RGR})$ of quinoa at different stages of crop growth as influenced by crop geometry $(\mathrm{cm})$

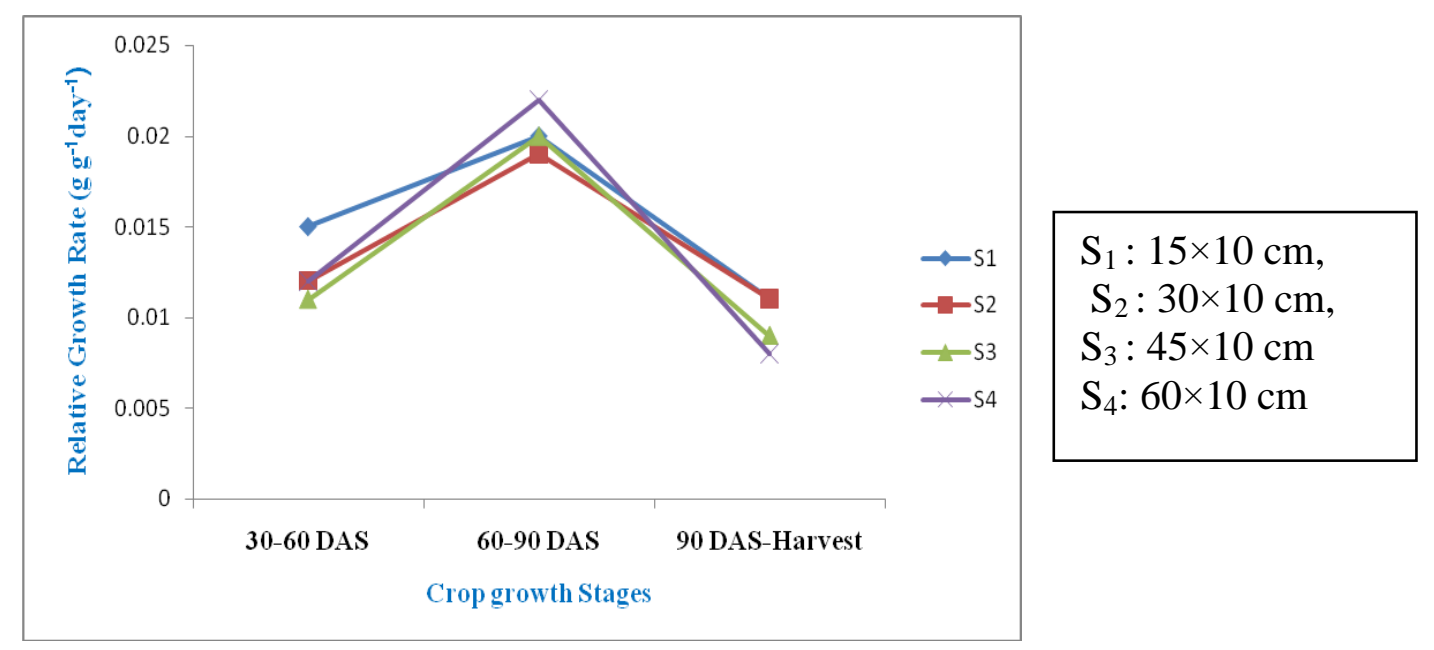


Fig.3 Net assimilation rate $\left(\mathrm{g} \mathrm{day}^{-1} \mathrm{~m}^{-2}\right)$ (NAR) of quinoa at different stages of crop growth as influenced by dates of sowing

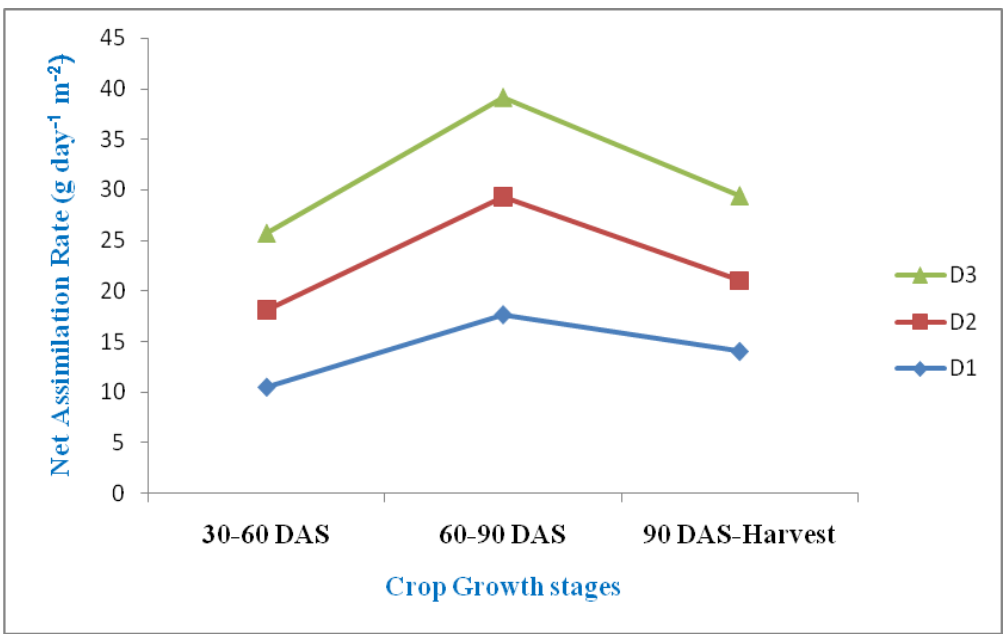
$\mathrm{D}_{1}: 15^{\text {th }}$ October
$\mathrm{D}_{2}: 1^{\text {st }}$ November
$\mathrm{D}_{3}: 16^{\text {th }}$ November

Fig.4 Net assimilation rate $\left(\mathrm{g} \mathrm{day}^{-1} \mathrm{~m}^{-2}\right)$ (NAR) of quinoa at different stages of crop growth as influenced by crop geometry $(\mathrm{cm})$

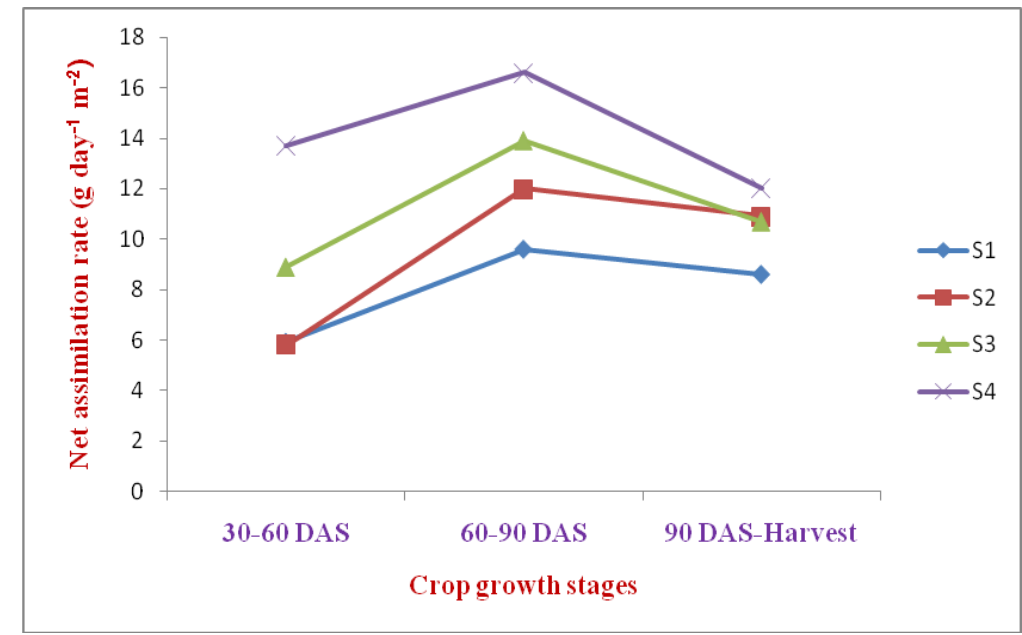

$\mathrm{S}_{1}: 15 \times 10 \mathrm{~cm}$

$\mathrm{S}_{2}: 30 \times 10 \mathrm{~cm}$,

$\mathrm{S}_{3}: 45 \times 10 \mathrm{~cm}$

$\mathrm{S}_{4}: 60 \times 10 \mathrm{~cm}$

The results indicated that GDD of each phenophase and total crop period was influenced due to sowing dates. Growing degree days were higher in January $2{ }^{\text {nd }}$ week $\left(17.1^{0} \mathrm{C}\right)$ and higher during October 15 to $22^{\text {nd }}\left(23^{0} \mathrm{C}\right)$.

Total growing degree days were higher (2119.1) with $15^{\text {th }}$ October date of sowing and was followed by $1{ }^{\text {st }}$ November (1959.3) and $16^{\text {th }}$ November (1857.5) dates of sowing. The same range of growing degree days (20002200) was reported by Hirich et al., (2014) in
Morocco.

In different phenophases, $15^{\text {th }}$ October date of sowing recorded more growing degree days (273) for germination and establishment than $1^{\text {st }}$ November (220) date of sowing and 16 th November (187). It may be due to higher average temperature $\left(22.85{ }^{0} \mathrm{C}\right)$ than 1 st November $\left(22.15^{0} \mathrm{C}\right)$ and $16{ }^{\text {th }}$ November $\left(20.55^{\circ} \mathrm{C}\right)$ dates of sowing.

The vegetative stage attained less growing degree days (727) during $15^{\text {th }}$ October date of 
sowing compared to $1{ }^{\text {st }}$ November (740) and $16^{\text {th }}$ November (723) date of sowing. The vegetative growth of quinoa interms of plant height, number of branches plant ${ }^{-1}$, dry matter of stem and leaf was less compared to 1 November and 16 th November dates of sowing. Growing degree days of flowering, grain initiation and development stages (431 and 416) was higher in $15^{\text {th }}$ October date of sowing compared to $1^{\text {st }}$ November (325 and 409 ) and $16^{\text {th }}$ November date of sowing (266 and 399). Hence relatively higheryield attributes (panicle length, number of grains panicle $^{-1}$ ) and seed yield was observed in $15^{\text {th }}$ October date of sowing. Grain hardening and maturity stages of quinoa attained higher growing degree days (282) in 15 th October date of sowing followed by 16 th November (273) and $1{ }^{\text {st }}$ November (268) dates of sowing.

\section{Photothermal units (PTU)}

Photothermal units represents the influence of photoperiod (day length) and temperature on growth and development of crop (Table 2). Quinoa is a short day plant and photoperiod had strong influence on reproductive phase (Bertero et al., 1991). The lower day length of 10.99 was observed during December to January and higher day lenghth of 11.65 was observed in October during crop growth period of quinoa.

Photothermal units (PTU) recorded in 15 October date of sowing was higher (23761) than $1{ }^{\text {st }}$ November (22060) and 16 th November (20636) date of sowing. photpthermal units during germination and estblishment and vegetative stages were almost similar for three dates of sowing, but $15^{\text {th }}$ October date of sowing recorded higher number of photothermal units during flowering (4765) and grain initiation and development (4570) stages mainly because of more number of days in these phenological stages. Sajjad et al., (2014) also reported sensitivity of quinoa genotypes to photoperiod and temperature. Photothermal units during grain hardening and maturity stage showed less variation due to dates of sowing. Bertero et al., (1991) reported that combination of high temperature with long day length (>14 h) showed greatest inhibitiion of seed growth by 73 per cent.

\section{Yield attributes and yield}

Panicle length $(\mathrm{cm})$, Number of panicles plant $^{-1}$, Number of spikelets panicle $\quad-1$, Number of grains panicle ${ }^{-1}$, Panicle weight (g $\left.\mathrm{m}^{-2}\right)$, Seed yield $\left(\mathrm{kg} \mathrm{ha}^{-1}\right)$ and Stalk yield $(\mathrm{kg}$ $\mathrm{ha}^{-1}$ ) were recorded significantly higher on $15^{\text {th }}$ October date of sowing compared to other dates of sowing ( Table 3). $\mathrm{T}$ he superiority of October 15 th date of sowing with respect to yield attributes and yield may be due to efficient utilization of natural resources (water and nutrients) with optimum vegetative growth and higher translocatation of photosynthates from source to sink. Similar results were reported by Hakan Geren et al.,(2014) and Sajjad et al., (2014) in Quinoa and Chaudhari et al., (2009) in amaranth crop. Parvin et al., (2013) also stated that late planting reduces yield because the plant life cycle is limited with temperature and photoperiod.

Among various crop geometries, $45 \mathrm{~cm} \times 10$ $\mathrm{cm}$ recorded signficantly higher panicle length, number of grains panicle ${ }^{-1} 60 \times 10 \mathrm{~cm}$ recorded higher number of panicles plant $\quad-1$, and number of spikelets panicle ${ }^{-1}$, where as higher Panicle weight, Seed and Stalk yield $\left(\mathrm{kg} \mathrm{ha}^{-1}\right)$ were recorded with $15 \times 10 \mathrm{~cm}$ as compared to the other crop geometries. The plants grown in wider spacing grew broader with more number of branches, number of panicles and increased panicle length due to availability of light, space, nutrients for single plant. Chaudhari et al., (2009) also reported higher panicle length and spikelets due to 
lower inter row competetion for space, nutrients and moisture in wider row spacing $(45 \times 10 \mathrm{~cm}$ and $60 \times 10 \mathrm{~cm})$ than narrow $15 \times$ $10 \mathrm{~cm}$ and $30 \times 10 \mathrm{~cm}$ ) spacings.

\section{Interaction effect between date of sowing and varied crop geometry on Physiological indices and yield of quinoa}

The interaction between dates of sowing and varied geometry was significant on crop growth rate at 30-60 DAS and 60-90 DAS (Table 1a). Within each date of sowing, CGR was significantly higher in narrow spacing $(15 \times 10 \mathrm{~cm})$ with sharp decline with increase in spacing from $30 \times 10 \mathrm{~cm}$ to $60 \times 10 \mathrm{~cm}$ spacing. At 30-60 DAS and at 60-90 DAS, higher CGR (9.8 and 18.9) was observed with $15^{\text {th }}$ October date of sowing at $15 \times 10 \quad \mathrm{~cm}$ spacing and was at par with same spacing at $1^{\text {st }}$ November date of sowing and during 3060 DAS, it was also at par with $1{ }^{\text {st }}$ November date of sowing at $60 \times 10 \mathrm{~cm}$ spacing.

Interaction effect of date of sowing and varied crop geometry on number of panicles plant ${ }^{-1}$, number of spikelets panicle ${ }^{-1}$ and stalk yield was found as non significant (Table 3a). Among the treatment combinations, panicle length of $28.4 \mathrm{~cm}$ was significantly higher with $15^{\text {th }}$ October date of sowing in $45 \times 10 \mathrm{~cm}$ spacing and was at par with same date of sowing with $60 \times 10 \mathrm{~cm}$ spacing. Higher number of grains panicle ${ }^{-1}$ was found at $15^{\text {th }}$ October date of sowing with $45 \mathrm{~cm} \times 10 \mathrm{~cm}$ spacing (18877) followed by same date of sowing with $60 \times 10 \mathrm{~cm}$ spacing (13452). The $15^{\text {th }}$ October $\left(725.2 \mathrm{~g} \mathrm{~m}^{-2}\right)$ and $1^{\text {st }}$ November $\left(730.0 \mathrm{~g} \mathrm{~m}^{-2}\right)$ dates of sowing with $15 \times 10 \mathrm{~cm}$ spacing were found at par and recorded significantly higher panicle weight compared to other combinations. The October $15^{\text {th }}$ date of sowing recorded higher seed yield when grown under $15 \times 10 \mathrm{~cm}(2392 \mathrm{~kg}$ ha followed by same date of sowing with $30 \times 10 \mathrm{~cm}\left(2083 \mathrm{~kg} \mathrm{ha}^{-1}\right)$ spacing that was at par with $1{ }^{\text {st }}$ November date of sowing with $15 \times 10 \mathrm{~cm}$ spacing $\left(2064 \mathrm{~kg} \mathrm{ha}^{-1}\right)$.

Higher crop growth rate, relative growth rate, total growing degree days and photothermal units was obtained on 15 th October date of sowing. H igher CGR , NAR and RGR was recorded with narrow $(15 \times 10 \mathrm{~cm})$ spacing. Among the yield attributes, number of panicles plant ${ }^{-1}$ was higher in $1{ }^{\text {st }}$ November and $16^{\text {th }}$ November dates of sowing. The panicle length, number of spikelets panicle ${ }^{-1}$ and number of grains panicle ${ }^{-1}$ was recorded higher at $15^{\text {th }}$ October date of sowing. Among geometry levels, number of branches plant ${ }^{-1}$, panicle length, number of spikelets panicle were higher under wider spacing $45 \times 10 \mathrm{~cm}$ and $60 \times 10 \mathrm{~cm}$ compared to narrow $(15 \times 10$ $\mathrm{cm})$ spacings. The highest seed and stalk yield were obtained with 15 th October date of sowing with narrow $(15 \times 10 \mathrm{~cm})$ spacing and was followed by $30 \times 10 \mathrm{~cm}$.

\section{References}

Bertero, H.D., King, R.W and Hall, A.J.1991. Photoperiod sensitive development phases in quinoa (Chenopodium quinoa willd.). Field crops Research (60) :231-243.

Bertero,H. 2001. Effect of photoperiod, Temperature and radiation on the rate of leaf appearance in quinoa

(Chenopodium quinoa willd.) under field condtions. Annals of Botany (87):495-502.

Bhargava, A.,Sudhir, S and Deepak Ohri. 2006. Quinoa (Chenopodium quinoa willd.).An Indian perspective. Industrial crops and products (23):73-87.

Chaudhari, J.H., Raj, V.C., Srivastava, K. and Ahir, M.P. 2009. Effect of varying sowing date and row spacings on yield attributes and yields of Rabi grain amaranth ( Amaranthus hypochondriacaus L. ) under South 
Gujarat conditions. Agricultural Science Digest,29(2):66-68.

FAOSTAT (2013).Quinoa area and production in the World.http://www.fao.org

Hakan Geren., Tuncer, K., Gulcan, D.T., Siddika, E and Deniz, I. 2014. Effect of differentsowing dates on the grain yield and some yield components of Quinoa (Chenopodium quinoa Willd.) grown under Mediterranean climatic conditions. Ege University, Ziraat Fakultesi. 51(3):297-305

Hirich, A.,Choukr -Allah, R and Jacobsen, S.E. 2014. Quinoa in Morocco - Effect of sowing dates on development and yield. Journal of Agronomy and Crop Science: $1-7$

Jacobsen, S.E. 2003. The world potential for Quinoa (Chenopodium quinoa willd.). Food Reviews International (19):167177.
Major, D.J., Joanson, D.R., Tanner, J.W and Anderson, I.C.1975. Effect of the day length and temperature on soyabean development. Crop Science (15): 174179

Parvin, N.,Islam, M.R., Nessa, B., Zahan, A., Akhand, MIM. 2013. Effect of sowing time and plant density on growth and yield of amaranth. Eco-friendly Agriculture Journal 6 (10): 215-219.

Rajput, R.P. 1980. Response of Soyabean crop to climatic and soil environments. Ph.D. Thesis, IARI,New Delhi,India.

Sajjad, A., Munir, H., Ehsanullah, Anjum, S.A., Tanveer, M., and Rehman, A. 2014. Growth and development of quinoa (Chenopodium quinoa willd.) at different sowing dates. Journal of Agricultural Research.52 (4):535-546.

Srinivasa Rao, K., Sarikotha panta quinoa, Sakhi News Paper page:10 on 11.08.2015

\section{How to cite this article:}

Ramesh, K., K.B. Suneetha Devi, K.A. Gopinath and Uma Devi, M. 2017. Physiological Indices, Yield and Yield Attributes of Quinoa (Chenopodium quinoa Willd.) as Influenced by Dates of Sowing and Varied Crop Geometry. Int.J.Curr.Microbiol.App.Sci. 6(7): 1023-1034. doi: https://doi.org/10.20546/ijcmas.2017.607.123 